\title{
Desirable Characteristics of Alternative Educators in Thai Social Reform
}

\author{
Poschanan Niramitchainont ${ }^{1}$ \\ ${ }^{1}$ Faculty of Social Sciences and Humanities, Mahidol University, Nakhon Pathom, Thailand \\ Correspondence: Poschanan Niramitchainont, Educational Management (International Program), Department of \\ Education, Faculty of Social Sciences and Humanities, Mahidol University, Salaya, Butthamonthon, Nakorn \\ Pathom 73170, Thailand. E-mail: poschanan.nir@mahidol.ac.th
}

\author{
Received: February 18, 2013 Accepted: March 21, 2013 Online Published: April 27, 2013 \\ doi:10.5539/ass.v9n5p183 URL: http://dx.doi.org/10.5539/ass.v9n5p183
}

\begin{abstract}
This study aims to explore the global megatrends and the chronic problems of Thailand for studying the roles of alternative educators that can be a part in Thai social reform; then identify the desirable characteristics which can perform these roles. The study conducts as both qualitative and quantitative methods with experts in alternative studies and human resource development in all fields. The analyses indicate that the global megatrends which will affect Thailand in the year 2021 are: aging society, urbanization, emerging infectious diseases, food insecurity, competition in technological development, world crude oil prices volatility, snatching natural resources, economic powerhouse of East Asia, global warming, climate change, regulations and good governance on environment. Thailand's chronic problems are social inequality, unsustainable country development and education separated from learners' way of life. The role of alternative educators in Thai social reform are to develop the new education system, fulfill the quality for Thai education and develop the learners who can effectively live and cope with the global megatrends. As a result, the desirable characteristics of alternative educators in Thai social reform are 21 st century skills, knowledge in education and human resource development, professional skills, morality, leadership, thinking skills and personal characteristics. The development model for the desirable characteristics of alternative educators should be realistic, holistic and flexible for each philosophy of alternative studies. Teaching them both theoretical knowledge along with authentic experiences; in order to learn and analyze social contexts, social problems, educational problems and use education in solving those kind of problems.
\end{abstract}

Keywords: alternative studies, desirable characteristics of alternative studies instructors, social reform, foresight

\section{Introduction}

Over recent years, Thailand has been facing all aspects of crisis such as economic, social, and environmental caused by both internal and external factors. Civil society and academic institutes all agree that there should have a big reform which is counted as the complete overhaul of Thailand. Education has prioritzed as one of the most important issues of Thai social reform since educational crisis has been a chronic problem in Thai society for a long period. Most of Thai students spend time for their education both in school and after school, but the overall attainments fail. This question has raised to Thailand's mainstream education; which can not produce human resources who can fulfill the needs of society as well as learners themselves (Vasi, 2010).

Thailand has attempted to push forward the improvement of the present education system, which can not achieve the society's goal. In 1999, Thailand offered Education Reform under the National Education Act B.E. 2542 (1999) and Amendments B.E. 2545 (2002), which initiated various innovations of education management, such as, giving opportunities to participate in education management to individuals, families, communities, community organizations, local administration organizations, private persons, private organizations, professional bodies, religious institutions, enterprises and other social institutions. This has allowed alternative studies to be a new player in Thailand's education system over the past 10 years (Office of the National Education Commission, 2005). As a result, alternative studies have become another choice while the mainstream education has severely been criticized for its failure of education management until some groups of educators have offered to overthrow the school system.

Alternative studies is the education which consider and develop learners as their individual differences. Hence, 
Alternative studies is various under the same objectives: to fulfill the individual needs, to use learning as a tool for developing learners to be excellent in holistic approach and to solve the problem of the present education system in order to be an alternative choices of proper education for all groups of people. It is also a kind of decentralizes of educational management to people so that they have rights and freedom to manage education themselves. Therefore, the prominent point of alternative studies is to develop potentials of individuals along with to solve social problems. It focuses on the learning process which gives priority to problems, not to curriculum and manages education in accordance with the tendency of today global situations which dramatically change. (Barr \& Parrett, 1997; Chakpisuth, Thongdeelert, Sukhongkaruttanakul, Tiersakul, \& Somphong, 2005; Cheryl \& Sandra, 2002; Glassman, Naidoo, \& Wood, 2007; Nagata, 2007; Raywid, 1983). Alternative studies is another way to develop human resources in each context and each profession; to be able to work or live evenly in the globalized age and to fulfill the needs of the society. The concepts of alternative studies conform to the research finding of Thailand scenario in the year 2020 which presents the role of alternative studies in solving the problem of substandard education. Therefore, the alternative studies institutes have to change their roles to be the knowledge facilitators who integrate the core knowledge with intelligence of locality on the basis of local participation. The alternative studies can lead to the development of the existing intelligence and to the innovation of knowledge under Thai social context which considers the diversity of religions, cultures, and races as well as genders (Knowledge Network Institute of Thailand, 2010; Sivaraksa, 2002).

Alternative educators are inputs and have major roles in driving the alternative studies; to arise and to efficiently continue in Thai society. Nowadays there is no any organization in Thailand that has seriously given priority to teacher development in the area of alternative studies which is different from teachers in formal school system who are supported by governmental organizations with policies and budgets. As the Teachers' Council of Thailand (2005) set the standard of teaching profession which is composed of teacher competencies and development models: for instance the teachers in formal schools get an attractive salary and benefit, job security and training continuously. In addition, there are quite a few researches on the context of alternative studies in Thailand.

As mention earlier about the need of Thai social reform, this research aimed to explore the global megatrends and the chronic problems of Thai society which will affect Thailand in the year 2012; for studied the roles of alternative educators that can be a part in Thai social reform; and identified the desirable characteristics of alternative educators which can perform the roles of Thai social reform. This research will be the beginning point and help pointing out the direction of Thailand's social movement, the relevance of alternative studies and society. Additionally, this research will clarify the roles of alternative educators in the change management and chronic social problem solving as well as in curriculum changing for developing of desirable characteristics, which there is no any organization that has seriously given priority to. Therefore, this research will provide policy recommendations which will lead to making better decisions in the development of alternative studies and its educators of Thailand in the future.

\section{Method}

This research conducted as both qualitative and quantitative methods in studying the desirable characteristics of alternative educators in Thai social reform.

\subsection{Research Design}

Qualitative method: three qualitative methods were used in this study: trend identification was used to explore the global megatrends; documentary research was used to explore the chronic problems of Thai society which will affect Thailand in the year 2012 for studying the roles of alternative educators that can be a part in Thai social reform and focus group discussion was used to consider and confirm the "(draft) Desirable Characteristics of Alternative Educators in Thai Social Reform."

Quantitative method: both online real-time and manual Delphi surveys were used to identify the desirable characteristics of alternative educators in Thai social reform. The Delphi survey also conducted as qualitative method in asking the key informant's opinions about additional information of alternative educators and their development model.

\subsection{Samples and Sampling Procedures}

This research had two groups of samples which were:

1) The group of fifty-four experts who answered Delphi survey. This group of experts was selected by purposive sampling from experts in the fields related to driving forces in technology, economics, environment and politics, 
especially in social, education and alternative studies.

2) The group of seven experts who were key informants in focus group discussion about "(draft) Desirable Characteristics of Alternative Educators in Thai Social Reform." This group of experts was selected by purposive sampling from experts in the area of alternative studies and higher education; who had answered the Delphi Survey.

\subsection{Research Procedures}

Using trend identification for exploring the global megatrends: including technology, economics, environment, politics, inclusively in social and education aspects. Documentary research was utilized to explore chronic problems of Thai society; both in overall Thailand and in education system. Then, researcher used the results of the global megatrends and the chronic problems of Thai society which will affect Thailand in the year 2012 as initial informations in identifying the roles of alternative educators that can be a part in Thai social reform.

Conducting Delphi survey: researcher used the result of analyzing the roles of alternative educators that can be a part in Thai social reform to be initial informations for developing the Delphi survey on desirable characteristics of alternative educators in social reform. There were both online real-time Delphi survey and manual Delphi survey available for experts to answer (the online real-time Delphi survey was uploaded on website with using instructions in detail). The experts who were convenient to answer the online real time survey received login ID, password, and reminder for responding. In case of experts who preferred to answer Delphi survey manually, the manual survey was sent by post or email. Each of experts answered two rounds of Delphi survey. The first round was that all experts gave their opinions in which they could not see the other experts' answer. In the second round, all experts could see all of other experts' answer, but only as overall answers, not as individual. Additionally, they could change their answers or gave their more opinions as qualitative data in the second round. Researcher took two months in collecting data. Then, researcher closed the system to evaluate and summarize the data.

Drawing up "(draft) Desirable Characteristics of Alternative Educators in Thai Social Reform". Then researcher arranged the round table session. Seven experts in the area of alternative studies and higher education who had answered the Delphi Survey were invited to give their opinions on "(draft) Desirable Characteristics of Alternative Educators in Thai Social Reform". Researcher brought the expert's opinions to readjust and finalize the "Desirable Characteristics of Alternative Educators in Thai Social Reform", and suggested the recommendation to develop the alternative educators.

\subsection{Data analysis}

The content analysis was used to analyze the global megatrends and the chronic problems of Thai society; which will affect Thailand in the year 2012; for studying the roles of alternative educators that can be a part in Thai social reform.

The analysis of mean, minimum - maximum, standard deviation, median and interquartile range (IQR) via SPSS for Windows Program were used to analyze the compatibility and the range distribution of experts' opinions from Delphi survey; for identifying the desirable characteristics of alternative educators which can perform the roles of Thai social reform.

\section{Results}

3.1 Global Megatrends and the Chronic Problems of Thai Society Which Will Affect Thailand in the Year 2012 for Studying the Roles of Alternative Educators That Can Be a Part in Thai Social Reform

From using trend identification to explore the global megatrends which will affect Thailand in 2021 could be considered from 5 aspects: (1) social aspect was aging society, urbanization, emerging infectious diseases and food insecurity, (2) technological aspect was intensive competition in technological development, (3) economics aspect was impacts of world crude oil prices volatility, severely snatching natural resources, and becoming economic powerhouse of East Asia, (4) environmental aspect was global warming and the severe impacts of climate change, and (5) legal and political aspect was increase of regulation and good governance on environment and on changes of entering ASEAN Community in 2015. From using documentary research to explore the chronic problems of Thai society both in overall Thailand and in education system found that Thailand had a lot of issues such as social inequality, and also focused mainly on economic development. The forms of development in Thailand over the past year were not sustainable. Thailand therefore lacks the ability to compete and confront economic problems in almost every decade such as the global and domestic economic crisis. Even during the economic growth, Thailand faced other challenges such as social problems. There were continuous social problems. Furthermore, education problems have been Thailand's chronic problem for a long 
period. In other words, education has still been separated from learners' way of life. Also, education management has been inefficient. Thailand's education has developed only quantitatively by increasing the number of learners, not qualitatively by improving the quality of learners. Thai people cannot use their literacy as a tool of self learning and apply lots of available knowledge to their daily life.

As a result, the roles of alternative educators which could be a part of social reform; were to develop new education system and produce learners who could efficiently live and deal with the global megatrends. The reforem will affect Thai society as well as cope with Thailand's chronic problems, especially to fulfill the quality of Thailand's education system.

\subsection{Desirable Characteristics of Alternative Educators in Thai Social Reform}

From using result of the roles of alternative educators that could be a part in Thai social reform to be the initial informations for developing the Delphi survey on desirable characteristics of alternative educators in social reform. Then conducting Delphi survey (both online real-time Delphi survey and manual Delphi survey) with fifty-four experts who were in the fields related to driving forces in technology, economics, environment, politics, especially in social, education and alternative studies. Each of experts must answered two rounds of Delphi survey to confirm their answer and researcher picked up the conform answer (IQR $\leq 1)$. The details shown in Table 1.

Table 1. Desirable characteristics of alternative educators in Thai social reform

\begin{tabular}{|c|c|c|c|c|c|c|}
\hline & Min & Max & $\mathrm{X}$ & Median & SD & IQR \\
\hline \multicolumn{7}{|l|}{$21^{\text {st }}$ century essential skills } \\
\hline Thai and English language & 2.00 & 4.00 & 3.35 & 3.00 & 0.55 & 1.00 \\
\hline Computer basic skills & 2.00 & 4.00 & 3.33 & 3.00 & 0.58 & 1.00 \\
\hline Communication* & 1.00 & 4.00 & 2.93 & 3.00 & 0.91 & 2.00 \\
\hline Social and cross-cultural skills & 1.00 & 4.00 & 3.46 & 4.00 & 0.66 & 1.00 \\
\hline Readiness for the ASEAN Community & 2.00 & 4.00 & 3.59 & 4.00 & 0.60 & 1.00 \\
\hline Lifelong learner & 2.00 & 4.00 & 3.81 & 4.00 & 0.48 & 0.00 \\
\hline ICT literacy & 2.00 & 4.00 & 3.31 & 3.00 & 0.54 & 1.00 \\
\hline Global awareness & 2.00 & 4.00 & 3.78 & 4.00 & 0.46 & 0.00 \\
\hline Citizenship & 2.00 & 4.00 & 3.67 & 4.00 & 0.51 & 1.00 \\
\hline \multicolumn{7}{|c|}{ Knowledge in education and human resource development } \\
\hline Educational management & 1.00 & 4.00 & 3.30 & 3.00 & .74 & 1.00 \\
\hline Curriculum development & 2.00 & 4.00 & 2.87 & 3.00 & .73 & 1.00 \\
\hline Educational research & 1.00 & 4.00 & 3.41 & 3.50 & .69 & 1.00 \\
\hline Educational innovation & 2.00 & 4.00 & 3.22 & 3.00 & .69 & 1.00 \\
\hline Teaching and training management & 3.00 & 4.00 & 3.80 & 4.00 & .41 & 0.00 \\
\hline $\begin{array}{l}\text { Educational measurement and } \\
\text { evaluation. }\end{array}$ & 2.00 & 4.00 & 3.74 & 4.00 & .52 & 0.00 \\
\hline Educational psychology & 2.00 & 4.00 & 3.70 & 4.00 & .50 & 1.00 \\
\hline Learning need assessment & 2.00 & 4.00 & 3.93 & 4.00 & .33 & 0.00 \\
\hline \multicolumn{7}{|l|}{ Professional skills } \\
\hline Professional proficiency & 3.00 & 4.00 & 3.89 & 4.00 & .32 & 0.00 \\
\hline $\begin{array}{l}\text { Continuous development of professional } \\
\text { proficiency }\end{array}$ & 2.00 & 4.00 & 3.76 & 4.00 & .51 & 0.00 \\
\hline $\begin{array}{l}\text { Professional networking (Within } \\
\text { education profession) }\end{array}$ & 2.00 & 4.00 & 3.48 & 4.00 & .61 & 1.00 \\
\hline Professional networking (Between other & 2.00 & 4.00 & 3.00 & 3.00 & .80 & 2.00 \\
\hline
\end{tabular}




\begin{tabular}{|c|c|c|c|c|c|c|}
\hline & Min & Max & $\mathrm{X}$ & Median & SD & IQR \\
\hline \multicolumn{7}{|l|}{ professions)* } \\
\hline Stakeholder networking & 2.00 & 4.00 & 3.33 & 3.00 & .58 & 1.00 \\
\hline \multicolumn{7}{|l|}{ Morality } \\
\hline Religious doctrines & 2.00 & 4.00 & 3.78 & 4.00 & .50 & .00 \\
\hline Professional ethics & 3.00 & 4.00 & 3.98 & 4.00 & .14 & .00 \\
\hline Good governance & 2.00 & 4.00 & 3.31 & 3.00 & .64 & 1.00 \\
\hline Social responsibility & 2.00 & 4.00 & 3.81 & 4.00 & .44 & .00 \\
\hline Public mind & 2.00 & 4.00 & 3.30 & 3.00 & .60 & 1.00 \\
\hline \multicolumn{7}{|l|}{ Leadership } \\
\hline Visionary & 3.00 & 4.00 & 3.33 & 3.00 & .48 & 1.00 \\
\hline Holistic view & 1.00 & 4.00 & 2.67 & 3.00 & .78 & 1.00 \\
\hline Transformational leadership & 2.00 & 4.00 & 3.78 & 4.00 & .46 & 0.00 \\
\hline Proactive* & 2.00 & 4.00 & 3.09 & 3.00 & .76 & 1.25 \\
\hline Team building and development* & 1.00 & 4.00 & 3.06 & 3.00 & .86 & 2.00 \\
\hline Strategic planning* & 1.00 & 4.00 & 3.02 & 3.00 & .84 & 2.00 \\
\hline Empowerment & 2.00 & 4.00 & 3.81 & 4.00 & .44 & 0.00 \\
\hline \multicolumn{7}{|l|}{ Thinking skills } \\
\hline Creative thinking & 1.00 & 4.00 & 3.80 & 4.00 & .53 & 0.00 \\
\hline Innovative thinking & 1.00 & 4.00 & 3.81 & 4.00 & .55 & 0.00 \\
\hline Future thinking & 2.00 & 4.00 & 3.81 & 4.00 & .44 & 0.00 \\
\hline Critical thinking & 1.00 & 4.00 & 3.85 & 4.00 & .49 & 0.00 \\
\hline Logical thinking* & 2.00 & 4.00 & 3.20 & 3.00 & .86 & 2.00 \\
\hline Analytical thinking* & 2.00 & 4.00 & 3.07 & 3.00 & .82 & 2.00 \\
\hline Systems thinking* & 1.00 & 4.00 & 3.13 & 3.00 & .91 & 2.00 \\
\hline Strategic thinking & 2.00 & 4.00 & 3.78 & 4.00 & .46 & 0.00 \\
\hline \multicolumn{7}{|l|}{ Personal characteristics } \\
\hline Emotional intelligence & 2.00 & 4.00 & 3.83 & 4.00 & .47 & 0.00 \\
\hline Flexibility & 1.00 & 4.00 & 3.83 & 4.00 & .54 & 0.00 \\
\hline Self-leadership & 2.00 & 4.00 & 3.70 & 4.00 & .50 & 1.00 \\
\hline Productivity & 2.00 & 4.00 & 3.20 & 3.00 & .56 & 1.00 \\
\hline Curiosity to learn & 2.00 & 4.00 & 3.72 & 4.00 & .56 & 0.00 \\
\hline Knowledge sharing & 2.00 & 4.00 & 3.70 & 4.00 & .57 & 0.25 \\
\hline Organizational engagement & 2.00 & 4.00 & 3.78 & 4.00 & .46 & 0.00 \\
\hline Positive attitude toward organization & 2.00 & 4.00 & 3.76 & 4.00 & .58 & 0.00 \\
\hline Interpersonal skills & 2.00 & 4.00 & 3.20 & 3.00 & .59 & 1.00 \\
\hline Open-mindedness & 3.00 & 4.00 & 3.89 & 4.00 & .32 & 0.00 \\
\hline Assertiveness & 1.00 & 4.00 & 3.81 & 4.00 & .62 & 0.00 \\
\hline Compromise* & 1.00 & 4.00 & 2.94 & 3.00 & .90 & 1.25 \\
\hline
\end{tabular}

*The experts opinion which were not conformed.

As shown in Table 1, the analyses found that there were seven groups of desirable characteristics of alternative 
educators in Thai social reform which composed of fourty-five components.

$21^{\text {st }}$ century essential skills which composed of eight components: (1) Lifelong learner, (2) Global awareness, (3) Citizenship, (4) Readiness for the ASEAN Community, (5) Social and cross-cultural skills, (6) Both Thai and English language, (7) Computer basic skills and (8) ICT literacy.

Knowledge in education and human resource development which composed of eight components: (1) Educational measurement and evaluation, (2) Teaching and training management (3) learning need assessment, (4) Educational psychology, (5) Educational research, (6) Educational management, (7) Educational innovation and (8) Curriculum development.

Professional skills which composed of four components: (1) Professional proficiency, (2) Continuous development of professional proficiency, (3) Professional networking (Within education profession) and (4) Stakeholder networking.

Morality which composed of five components: (1) Professional ethics, (2) Social responsibility, (3) Religious doctrines, (4) Good governance and (5) Public mind.

Leadership which composed of four components: (1) Empowerment (2) Transformational leadership, (3) Visionary and (4) Holistic view.

Thinking skills which composed of five components: (1) Critical thinking, (2) Innovative thinking, (3) Future thinking, (4) Creative thinking and (5) Strategic thinking.

Personal characteristics which composed of eleven components: (1) Open-mindedness, (2) Emotional intelligence, (3) Flexibility, (4) Assertiveness, (5) Organizational engagement, (6) Positive attitude toward organization, (7) Curiosity to learn, (8) Knowledge sharing, (9) Self-leadership, (10) Productivity and (11) Interpersonal skills.

The development model for desirable characteristics of alternative educators in Thai social reform should be holistic and flexible for each philosophy of alternative studies. Alternative educators should gain theoretical knowledge along with authentic experience based learning. They should learn and analyze social contexts, social problems, educational problems, child problems and juvenile delinquent; in order to clarify the roles of education in solving those kind of problems. The curriculum should focus on the alternative studies paradigm and learning process as well as on alternative studies management skills which emphasizes on collaboration with all stakeholders.

\section{Discussion}

4.1 Global Megatrends and the Chronic Problems of Thai Society Which Will Affect Thailand in the Year 2012 for Studying the Roles of Alternative Educators That Can Be a Part in Thai Social Reform

The study found that "The roles of alternative educators that could be a part of social reform; were to develop new education system and produce learners who could efficiently live and deal with the global megatrends which will affect Thai society as well as cope with Thailand's chronic problems, especially to fulfill the quality of Thailand's education system". The result presented that the social changes in 20th century have fully been caused by the driving forces of global megatrends which have affected Thailand and worldwide.The composing of aging society, urban growth, emerging infectious diseases, food insecurity, intensive competition in technological development, world crude oil prices volatility, severely snatching natural resources, becoming economic powerhouse of East Asia, global warming and its impacts, and increase of regulation and changes of entering ASEAN Community in 2015. (European Environment Agency, 2010; Fogel, 2009; United Nations,2009; U.S. Energy Information Administration, 2010). The chronic problems in Thailand composing of social inequality and unsustainable country development that has mainly focused on economics. The result of the study has revealed the similarity with many literatures which suggested that developed countries should use education as a tool to develop human resources so that they could innovate and apply knowledge to make benefits for their nations. Education is not only a rite of passage, but it is like the fifth requisite of an individual nowadays (Cheryl \& Sandra,2002; Mintz, 1996; Nakhonthap, 1994). Since Thailand faced the problem that mainstream education could not efficiently develop human resources and fulfill people's needs. Alternative educators could take part in social reform by developing new education system and producing learners who could efficiently live and deal with the global megatrends which will affect Thai society as well as cope with Thailand's chronic problems, especially to fulfill the quality of Thailand's education. The result did not mean to the whole nation's education system, but it is a part for learners who have special needs or in special contexts. Therefore, alternative educators should act not as an instructor, but as a learning facilitator who encourage learners to learn by their own. Alternative educators should be able to create a supportive learning environment; to connect to community and 
contexts in educational management. In such way, learners could learn from authentic experiences, problems and social situations. The finding as mentioned is in accordance with many forms of alternative studies managing concepts which all have the same objective; to create the quality education system for particular groups of learners. (Patoomchareonwattana, 2002) For instance, Children village school in Thailand managed education for underprivileged learners. (Chanvit \& Tunmuntong, 2012) Additionally, alternative education institutes in India were supported by United Nations Educational, Scientific and Cultural Organization (UNESCO). Also, Government of India supported alternative studies as a basic education for early childhood; as an adult education in order to give an opportunity to study to poor learners and to equalize the society. (Nagata, 2007). In New Zealand Rudolf Steiner Schools' Certificate (NZRSSC) managed education under the school education development in order to pass the education standard of the country. Alternative studies aimed at holistic learner development and presented the standard of its education. (Patterson, 2006)

\subsection{Desirable Characteristics of Alternative Educators in Thai Social Reform}

The study found that "There were seven desirable characteristics of alternative educators in Thai social reform which composed of fourty-five components: (1) 21 st century essential skills, (2) Knowledge in education and human resource development, (3) Professional skills, (4) Morality, (5) Leadership, (6) Thinking skills and (7) Personal characteristics". The finding found that the professional skills is the only one desirable characteristic that conformed to the concept of education reform in Thailand which gave priority to teacher and educational staff development, expecting to enhance the teaching career to be professional. (The Teachers' Council of Thailand, 2006). Experts in the focus group discussion session all agreed with this finding that apart from teaching skills, alternative educators should have the characteristic on the basis of Humanism perspective according to the natures of alternative studies and mainstream education are different. Alternative educators should change their roles to be learning facilitators. Alternative educators should believe that all the learners have equal worth and honor; they can learn and improve themselves. Alternative educators should respect learners as a human and continuously improve themselves in realistic and holistic approach. Additionally, in social contexts that rapidly change, alternative educations should have essential skills for the $21^{\text {st }}$ century, preparing themselves for ASEAN Community and giving awareness of their citizenship in order to prepare learners to deal with changes. So that they conjointly found out the ways and performed to develop the country. Alternative educators should realize that education is endless as lifelong education, and they should be a lifelong learner, adjusted themselves to the world's changes and improved themselves along with learners. They should have leadership and be able to realize, analyze, synthesize problems in society and use education as the solution of those problems in the aspects that mainstream education could not do.

In order to develop alternative educators to have the seven desirable characteristics, experts in the focus group discussion session suggested that there should be a specific curriculum which does not emphasize only on the subject itself. According to the paradigm, alternative studies was to realistically and holistically developed learners, its educators should be realistically and holistically developed as well. Additionally, as alternative studies tried to merge itself into learners' life, alternative educators should learn theoretical concepts altogether with authentic experience based learning, which was related to their contexts. They should learn and analyze social contexts, so that they could use alternative studies as a tool for learner developing and social problem solving.

\section{Recommendations}

\subsection{Policy Recommendations}

The study founded that the roles of alternative educators, which can be a part of social reform, were to develop new education system and fulfill the quality of Thailand's education system. Therefore, the ministry of education in Thailand should concern more and provide budgets for alternative studies as a system of education not only mainstream education (formal school). Additionally, alternative studies could be operated along with mainstream education for shared-resource management and cooperation with related organizations for educational management.

The study founded that the roles of alternative educators which can be a part of social reform; were to develop learners in the holistic approach and could efficiently live and deal the global megatrends and Thailand's chronic problems; which was the teachers in mainstream education could not do. Therefore,the formal school or organization in the field of human resource development could apply the concept of alternative studies in order to apply it to the development of human resource quality.

The study founded that the desirable characteristics of alternative educators were in the form of holistic approach did not consider only the academic knowledge. Therefore, alternative school, formal school or any organization 
which is responsible for teacher and educational staff development could apply this research finding to be a model for developing educator in holistic approach in the future.

\subsection{Recommendation for Future Research Directions}

As this research has presented the desirable characteristics of alternative educators in Thai social reform and development models. Therefore the alternative school, formal school or any organization which is responsible for teacher and educational staff development could use it as an information in designing training program for alternative educators or any educators in other contexts.

\section{Acknowledgements}

This research project is supported by Mahidol University, Thailand.

\section{References}

Barr, R., \& Parrett, W. H. (1997). How to Create Alternative, Magnet and Charter Schools that Work. Bloomington, IN: National Education Service.

Chakpisuth, S., Thongdeelert, C., Sukhongkaruttanakul, I., Tiersakul, L., \& Somphong, S. (2005). Alternative education: the world outside school. Bangkok, Thailand: The Thailand research fund.

Chanvit, P., \& Tunmuntong, S. (2012). Alternative schools and civil's education choice. Bangkok, Thailand: Development Research Institute.

European Environment Agency. (2010). The European environment state and outlook 2010 assessment of global megatrends. Luxembourg, Luxembourg: Office of the European Union.

Fogel, R. W. (2009). The impact of the Asian miracle on the theory of economic growth. Cambridge, UK: National Bureau of Economic Research. http://dx.doi.org/10.3386/w14967

Glassman, D., Naidoo, J., \& Wood, F. (2007). Community schools in africa: reaching the unreached. Boston, MA: Springer.

Knowledge Network Institute of Thailand. (2010). The scenarios of Thailand 2019. Bangkok, Thailand: Plus press.

Lange, C. M., \& Sletten, S. J. (2002). Alternative Education: A brief history and research synthesis (Project forum). Alexandria, VA: National Association of State Directors of Special Education.

Mintz, J. (1996). The Handbook of Alternative Education. New York, NY: Macmillan.

Nagata, Y. (2007). Alternative education: Global perspectives relevant to the Asia-Pacific Region. Dordrecht, Netherlands: Springer.

Nakhonthap, A. (1994). Dream of the land. Bangkok, Thailand: Eastern printing.

Office of the National Education Commission. (2005). National Education Act B.E. 2542 (1999) and Amendments (Second National Education Act B.E. 2545 (2002)). Bangkok, Thailand: Pimdeekarnpim.

Patoomcharoenwattana, V. (2002). Informal education and educational reform. Bangkok, Thailand: Chulalongkorn University.

Patterson, J. (2006). Developing a high school qualification for Steiner school: The New Zealand Rudolf Steiner Schools' Certificate. Journal for Waldorf/Rudolf Steiner Teachers, 8(2), 30-31.

Pravet, V. (2010). Thailand reform: The issues that should be reform. Nonthaburi, Thailand: Thailand reform office.

Raywid, M. A. (1983). Schools of Choice: Their Current Nature and Prospects. Phi Delta Kappan, 64(10), 684-688.

Sivaraksa, S. (2002). The future of alternative education in Thailand. Bangkok. Bangkok, Thailand: Bank of Thailand.

The Teachers' Council of Thailand. (2005). Regulation of the Teachers Council of Thailand on Professional Standards and Ethics B.E. 2548 (2005). Bangkok, Thailand: The Teachers' Council of Thailand.

Turnbull, S. (2006). The rate of learning to read in a Rudolf Steiner school. Journal for Waldorf/Rudolf Steiner Teachers, 8(2), 11-15.

U. S. Energy Information Administration. (2010). Annual energy outlook 2010: with projections to 2035. Washington, DC : Office of Integrated Analysis and Forecasting. U. S. Department of Energy.

United Nations. (2009). World population prospects: The 2008 revision, highlights. New York, NY: United Nations. 